\title{
Is the Creation under Destruction?: Abraham Kuyper and Herman Bavinck on New Creation
}

\author{
David Kristanto \\ Asian Center for Theological Studies and Mission (ACTS), South Korea \\ davidkristanto.id@gmail.com
}

\begin{abstract}
Perhaps there is no better time to reflect on the new creation than now, amid the Covid-19 pandemic. All aspects of human life are being impacted by the pandemic, not to mention the danger of death that it generates. This critical situation brings out legitimate questions to the current state of the world (or creation): whether it is perishing, being abandoned by God, or whether God is punishing the world into destruction due to its abundance of sin. Attempting to answer those questions, the author will argue alongside Kuyper and Bavinck that God would never abandon nor destroy his creation. Even though corrupted by sin, God has no intention to destroy the creation; instead, he intends to restore it according to his original plan. God's intention is not just to redeem the elect but to redeem the whole creation, and that complete redemption will find its fulfillment in the new creation. Such a reflection would encourage the Christian proclamation that God's salvation extends to all creation.
\end{abstract}

Keywords: New Creation, Creation, Abraham Kuyper, Herman Bavinck, Neo-Calvinism, Eschatology, Re-Creation, Salvation 


\section{INTRODUCTION}

Recent theological papers in Indonesia related to the Covid-19 pandemic tend to focus more on the practical side than the theological side. Widjaja et al. and Lukuhay encourage the practice of worshiping in the house-church (Gereja Rumah), ${ }^{1}$ whereas Dwiraharjo argues for the scriptural legitimacy of practicing online worship service. ${ }^{2}$ Those practical issues emerged as the effect of the government restriction of public gathering-including church gathering-which forbade public worship or at least restricted it in some ways.

Maintaining Christian worship is indeed a crucial question at this time; however, Christians also need to reflect upon theological themes that might encourage their faith during the pandemic. Questions such as, "Is the world ${ }^{3}$ being abandoned by God?" or perhaps expressed stronger, "Is the world being destroyed by God due to its sinfulness?" might legitimately be raised in the current situation.

Attempting to answer those questions, the author will argue alongside Abraham Kuyper and Herman Bavinck that God is not abandoning his creation nor intending to destroy

${ }^{1}$ Fransiskus Irwan Widjaja, et al., "Menstimulasi Praktik Gereja Rumah di tengah Pandemi Covid-19," Kurios: Jurnal Teologi dan Pendidikan Agama Kristen 6, no. 1 (2020): 127-139, https://doi.org/10.30995/kur. v6i1.166; and Alexander Stevanus Lukuhay, "Analisis Teologis Mengenai Beribadah di Rumah di Tengah Pandemi Covid-19 di Indonesia," Visio Dei: Jurnal Teologi Kristen 2, no. 1 (2020): 43-61, https://doi.org/ 10.35909/visiodei.v2i1.87.

${ }^{2}$ Susanto Dwiraharjo, "Konstruksi Teologis Gereja Digital: Sebuah Refleksi Biblis Ibadah Online di Masa Pandemi Covid-19" in Epigraphe: Jurnal Teologi dan Pelayanan Kristiani Vol. 4, No. 1 (2020): 1-17, https://doi.org/10.33991/epigraphe.v4i1.145.

${ }^{3}$ The term "earth" or "world" in this paper do not refer to the sinful state of the creation, but are used as synonymous to the term "creation". it. Instead, God intends to restore the whole creation into the new creation. The new creation should not be understood as something God created totally anew; instead, it should be understood as total restoration of this present creation into God's original plan from eternity. God who redeems the elect is the One who will redeem the whole cosmos into a new heaven and a new earth. Thus, grace does not abolish nature but restores and perfects it. Hopefully, this reflection would bear a firm conviction that God's restorative work over whole creation would never fail despite sin. Even amid the pandemic, Christians are not called to live in endless anxiety but to proclaim that God's restorative work over his creation will not fail. The Gospel should not be understood as a message of salvation from the earth, but the salvation of the whole earth.

Kuyper and Bavinck will not be compared critically in this paper, but their positions will be considered complementary. Therefore, only significant differences (if any) between them will be discussed. This paper will attempt to draw a dogmatic sketch on Kuyper's and Bavinck's conception of the new creation, then reflect upon it to draw implications for Christian life amid the Covid-19 pandemic.

\section{GRACE RESTORES AND PERFECTS NATURE}

Neo-Calvinism ${ }^{4}$ has a strong conviction that grace does not abolish nature but restores

${ }^{4}$ Its adjective form, "Neo-Calvinistic", is considered synonymous to "Kuyperian" and "Reformational". However, the latest tends to refer to further developments, e.g. "Reformational Philosophy" and "Reformational Theology"; see Albert Wolters, "Dutch Neo-Calvinism: Worldview, Philosophy and Rationality" in Rationality in the Calvinian Tradition, eds. H. Hart, J. van der Hoeven, and Nicholas Wolterstorff (Eugene: Wipf and Stock, 2011), 117. 
and perfects it. ${ }^{5}$ This movement has Kuyper as its leader and pioneer, whereas Bavinck is considered as its most refined dogmatician. This type of Calvinism is called "neo" or "new" because even though Kuyper was a self-designated Calvinist, he never attempted to imitate Calvinism of the past merely. Kuyper wholeheartedly affirmed the principle of Calvinism and tried to build upon it a strong foundation to defend Christianity in modern times. ${ }^{6}$ In his exact word, he said that his Calvinism is not to imitate the past, "but to go back to the living root of the Calvinistic plant, to clean and to water it, and so to cause it to bud and to blossom once more, now fully in accordance with our actual life in the sense of modern times, and with the demands of the times to come."

The conviction grace restores nature could be seen clearly from how Kuyper perceived Calvinism. To him, it is more than just a theological position, confessional stance, or a kind of ecclesiastical polity. Instead, it is a dynamic vision that since the days of the Reformation had brought all kinds of societal transformations; first in Calvin's Geneva, the Huguenots in France, the Reformed in the Netherlands, the Puritans in England, the Presbyterians in Scotland, and also among the Pilgrim Fathers in the "New World." Thus Nicholas Wolterstorff rightly called it "World-Formative Christianity."

\footnotetext{
${ }^{5} \mathrm{Neo}-\mathrm{Calvinism}$ understands nature to refer to creation that includes all aspects of human life and culture, whereas grace to refer to the new life in Christ, redemption, and salvation; cf. Al Wolters, "The Nature of Fundamentalism", in Pro Rege 15, no. 1 (1986): 7, https:// digitalcollections.dordt.edu/pro_rege/vol15/iss1/2.

${ }^{6}$ John Bolt, A Free Church, a Holy Nation: Abraham Kuyper's American Public Theology (Grand Rapids: Eerdmans, 2001), 445.

${ }^{7}$ Abraham Kuyper, Lectures on Calvinism (1931; repr., Grand Rapids: Eerdmans, 2000), 171.

${ }^{8}$ Wolterstorff, Until Justice and Peace Embrace: The Kuyper Lectures for 1981 (Grand Rapids: Eerdmans, 1983) ch. 1, quoted in Jacob Klapwijk, “Abraham
}

Even though the conviction grace restores nature in Kuyper's thought is strongly expressed in terms of societal transformation, Neo-Calvinism's emphasis on transformation is not limited only to human beings. Neo-Calvinism also emphasizes that God's majesty expands to "the very ends of creation" and "nothing was outside his glory." One good example can be found in Roger Henderson's excellent article. He noted that there are two versions of the translation of Kuyper's famous adage,${ }^{10}$ i.e.

(1) There is not a square inch in the whole of creation over which Christ, who is Sovereign over all, does not cry: "Mine!"

(2) There is not a square inch in the whole domain of our human existence over which Christ, who is Sovereign over all, does not cry: "Mine!"

The second translation is the right one. ${ }^{11}$ However, Henderson argues that it is not without reason that the first translation exists. That is perhaps due to the phrases "the whole of" and also "over all" that might lead the tendency to modify it into the "whole of creation." He adds further, "Although logically incorrect, the wider claim seems somehow justifiable in the light of the narrower." The original context of the adage was Kuyper's speech at the inauguration of Vrije Universiteit Amsterdam. Therefore it implies how "all of the teaching, learning, research, administering, and writing has a place in, through, and to Christ" and thus

Kuyper on Science, Theology and University" Philosophia Reformata 78, no. 1 (2013): 19, https://doi.org/10. 1163/22116117-90000537.

${ }^{9}$ Bruce Gordon, John Calvin's Institutes of the Christian Religion: A Biography (New Jersey: Princeton University Press, 2016), 128.

${ }^{10}$ Roger Henderson, "Kuyper's Inch" in Pro Rege 36, no. 3 (2008): 12. https://digitalcollections.dordt. edu/pro_rege/vol36/iss3/2.

${ }^{11}$ In Dutch: "het menselijke bestaan." The second translation is from Abraham Kuyper, $A$ Centennial Reader, ed. James D. Bratt (Grand Rapids: Eerdmans, 1998), 488. 
anticipating "Christ's restoration of all things." 12 The sentiment that God's glory expands to all creation is also strong in $\mathrm{Ba}$ vinck's works. One example is how he repeatedly quoted from Calvin's Institutes that "there is no spot in the universe in which you cannot discern at least some sparks of his glory." 13

Neo-Calvinism does not see grace as something alien to nature but sees it as permeating nature. In Kuyper's words: "We cannot grasp grace in all its richness if we do not notice that the fibers of its roots penetrate into the joints and cracks of the life of nature." For him, grace and nature are closely connected. Christ's work does not merely deal with the soul, but also with the human body and he claims all the world as his. The culmination of those things is Christ's reign as the King of the new heaven and earth. And when it happens, "it becomes immediately apparent that grace is inseparably linked to nature, that grace and nature belong together." 14

It is difficult to see how grace and nature belong together since nature has been corrupted by $\sin$. The fall of humanity into sin, "is pulling the earth, and indeed the whole of God's creation down with it." But even after the fall, God did not abandon his creation. Instead, God had decided "a particular plan of action, namely common grace, followed by the history of particular grace." 15 Common

\footnotetext{
${ }^{12}$ Henderson, Kuyper's Inch, 12-13.

${ }^{13}$ Herman Bavinck, Reformed Dogmatics, 4 vols., ed. John Bolt, trans. John Vriend (Grand Rapids: Baker Academic, 2003-2008), 2:67, 69, 437; hereafter referenced as $R D$; cf. J. Calvin, Institutes, 1.5.1.

${ }^{14}$ Abraham Kuyper, Common Grace: God's Gifts for a Fallen World, vol. 1, trans. Nelson D. Kloosterman, ed. M. van der Maas (Bellingham: Lexham Press, 2015), 270. Hereafter referenced as $C G$; quoted in Craig G. Bartholomew, Contours of the Kuyperian Tradition: $A$ Systematic Introduction (Downers Grove: InterVarsity, 2017), 41.

${ }^{15}$ Ernst M. Conradie, "Revisiting Kuyper's Notion of Common Grace," in Creation and Salvation: Dialogue
}

grace is God's providence over the fallen creation that restrains evil, "keeping the impact of sin at bay," so it prevents "the selfdestruction of God's beloved creation." Without God's prevention, "sin would make life itself impossible." 16 Alternatively, in Kuyper's own words, without common grace, "life on earth would immediately have turned into a hell." On the other hand, God has given the creation of his particular grace. The basic difference between common grace and particular grace is that the latter is not offered to humankind in general but only given to the elects. And while the latter is salvific, the previous is not. ${ }^{17}$

Even though God's grace might be distinguished into common grace and particular grace, the unity between them should be maintained. One way to do it is to see them from the eschatological perspective. According to Kees van der Kooi, common grace has an eschatological function and goal in Kuyper's theology. Through common grace, "God brings the potencies of his creation into being and performs what he as Creator originally had in mind." Up to this point, it seems like common grace and particular grace are independent of each other due to their distinct significances: the first is cosmological, and the latter is personal (salvation). However, van der Kooi argues further that another concept of Kuyper's theological construct must be noted, and that is the notion of rebirth or, in Kuyper's term, "palingenesis." 18 Van der Kooi wrote:

on Abraham Kuyper's Legacy for Contemporary Ecotheology, ed. Ernst M. Conradie (Leiden: Brill, 2011), 102.

${ }^{16}$ Ibid., 104.

${ }^{17}$ See ibid., 100-101n17.

${ }^{18}$ The term is drawn from the Greek word palingenesia, which means rebirth or regeneration. Kuyper uses that Greek word because it covers both personal rebirth (Tit. 3:5) and the rebirth of all cosmos, a new heaven and a new earth (Matt. 19:28). Bartholomew argues that this is the key concept of the Kuyperian tradition; see Bartholomew, Contours of the Kuyperian Tradition, 27. 
Rebirth or palingenesis is not restricted to the individual human person, but also has a cosmic meaning. Palingenesis is a concept that was introduced in 1892 by Kuyper in his address on "blurring the boundaries." In fact, it was a concept that was fitted to carry the whole of his thought. Palingenesis is for him not only a personal process, in which the individual believer is restored and sanctified, but it is a process that also has a cosmic dimension. It encompasses the restoration and fulfillment of humanity as a whole and the powers of the universe. ${ }^{19}$

Kuyper's notion of rebirth or palingenesis shows that particular grace in Kuyper's thought also has a cosmic significance. Therefore, from the soteriological perspective (concerning their salvific effects), the two are very different. Nevertheless, if considered from the eschatological perspective, both common grace and particular grace are in unity due to their cosmic significances, since both are dealing with how grace restores nature. It may also argue further that the distinction between common grace and particular grace is temporary. After the fulfillment of God's re-creation, there will be no more distinction between them but only the abundance of God's grace in the new creation.

Bavinck strongly emphasizes an organic ${ }^{20}$ relation of nature and grace that is reflected

\footnotetext{
${ }^{19}$ Kees van der Kooi, "Gratia non tollit naturam, sed perficit" in Creation and Salvation: Dialogue on Abraham Kuyper's Legacy for Contemporary Ecotheology, ed. Ernst M. Conradie (Leiden: Brill, 2011), 218.

${ }^{20}$ Eglinton argues that Kuyper's and Bavinck's "organic" motif does not derive from German idealism but from Calvin's theology. This "organic" thinking is an attempt to see the reality as a reflection of the Trinity: "Organic thinking begins by seeing the universe as the general revelation of God's Trinity." Creation is consistently seen as "organic" whereas the Creator as "triune". Therefore, the genesis of the term is not pantheistic, and its telos is not monistic; see James Eglinton, "Bavinck's Organic Motif: Questions Seeking Answers" in Calvin Theological Journal 45, no. 1 (2010): 61-71.
}

through the central motif of his theology: "grace restores and perfects nature." This position is quite well established among the Bavinck scholarship circles, which opposes the Neoplatonic dualism in western theology. Neoplatonic dualism is a system of hierarchical ontology of nature and grace, which views spirit and matter as opposed to each other and thus produces pantheistic forms of theology. For Bavinck, the spiritual "cannot be considered as ontologically 'higher,' an elevation of, or superadditive to, the material in any sense." 21 Bavinck replaces the "vertical" dualism of "higher" and "lower" with "horizontal" duality between nature (state of integrity) and grace (state of glory). The second is not in opposition to the first. The "state of glory" is the organic fulfillment of God's purposes for the creation, which begins in its "state of integrity." In this sense, Bavinck could say that: "Christianity does not introduce a single substantial foreign element to creation. It creates no new cosmos but rather makes the cosmos new. It restores what was corrupted by sin. It atones the guilty and cures what is sick; the wounded it heals." 22

In Bavinck's understanding, grace would completely restore nature when the eschatological destination is finally reached. This eschatological destination is "a constitutive component of creation" that could be achieved through the covenant of works he defines as the "road to heavenly blessedness for the human beings, who were created in God's image and had not yet fallen." ${ }^{23}$ The restoration is not bringing us to Adam's original condition but the end of his journey. That is the condition of "what Adam had to become" by keeping the covenant of works.

\footnotetext{
${ }^{21}$ Brian G. Mattson, Restored to Our Destiny: Eschatology \& the Image of God in Herman Bavinck's Reformed Dogmatics (Leiden: Brill, 2012), 237.

${ }^{22}$ Ibid., 239; cf. Herman Bavinck, "Common Grace", trans. Raymond C. Van Leeuwen, in Calvin Theological Journal 24, no. 1 (April 1989): 61.

${ }^{23}$ Mattson, 240; Cf. $R D, 2: 572$.
} 
This covenant framework alone could explain why redemption is both a restoration and perfection at the same time as the creation in Bavinck's theology. The covenant of works is the "engine" of Bavinck's signature "grace restores and perfects nature." 24

\section{CREATION AND NEW CREATION}

Neo-Calvinism has a strong tendency to emphasize the continuity between creation and new creation. Kuyper wrote powerfully against the notion that the new creation will be totally anew because "God's honor depended on the fact that his glorious work of creation would ultimately be shown not to have failed but to have served the glorification of his name." ${ }^{25} \mathrm{He}$ argues for how at the end time, God will transform this world that has been corrupted by "the sins of angels and men" into "a perfect form of life," which corresponds to His original purpose of creation. ${ }^{26}$ That is also the case for Bavinck, in which he states: "God's honor consists precisely in the fact that he redeems and renews the same humanity, the same world, the same heaven, and the same earth that have been corrupted and polluted by $\sin .{ }^{27}$ In this case, both theologians agree upon the term "new" in "new creation" is not referring to something absolutely new. Instead, it refers to God's act of renewing or restoring all creation. ${ }^{28}$

\footnotetext{
${ }^{24}$ Ibid., 241.

${ }^{25} C G, 1: 291$; quoted in Bartholomew, Contours of the Kuyperian Tradition, 42.

${ }^{26}$ Abraham Kuyper, The Revelation of St. John, trans. John H. de Vries (Grand Rapids: Eerdmans, 1963), 344; quoted in Ibid., 42.

${ }^{27} R D, 4: 717$.

${ }^{28}$ Ortlund notes how Bavinck's emphasis on salvation is seemingly different than that of Jonathan Edwards. While Bavinck tends to think of salvation as "the healing of what was there, though marred through sin," Edwards tends to see it as "the implantation of something completely new;" See Dane C. Ortlund, "'Created Over a Second Time' or 'Grace Restoring Nature'? Edwards and Bavinck on the Heart of Christian Salvation" The Bavinck Review 3
}

Bartholomew criticizes Kuyper of being inconsistent on emphasizing the continuity between creation and consummation in his elaboration on how re-creation will occur. Even though Kuyper affirms re-creation as not something created anew and thus alien to the creation, but he is not consistent when taking 2 Peter 3:10 as literally saying that the creation will perish in the process of recreation: "First everything that exists will perish, and only then the new order will emerge out of that apparent chaos." To justify his position, Kuyper makes a distinction between form and essence. He argues that what will perish is the form, not the essence, and afterward, the essence will emerge in "new" and "more glorious forms." This distinction is regarded as "unhelpful" by Bartholomew. $^{29}$

Perhaps such a distinction is not totally "unhelpful," since we can also find it in Bavinck. He argues that sin, even though in the eyes of the Reformed theologians "spoiled and destroyed everything," but is not "a substance"; thus, "it could not alter the essence or substance of the creation." Sinful humans are still human beings, and other creatures, "despite sin's curse," remain essentially the same. ${ }^{30}$ For Bavinck, "What is changed is not the stuff (materia) of creation but its forma; creation was deformed by $\sin$ to be entirely reformed again in the sphere of grace." Grace does not restore the substance of things, for sin never took it away.

(2012): 11, 24, https://bavinckinstitute.org/wp-content/ uploads/2012/06/TBR3a-Ortlund1.pdf.

${ }^{29} C G$ 1:544, 572; quoted in Bartholomew, Contours of the Kuyperian Tradition, 42-43.

${ }^{30}$ Bavinck argues that there is distinction between the image of God in the narrower and the broader sense. Sin has made human lost the image of God in the narrower sense while the image of God in the broader sense is retained but "spoiled and ruined," thus the whole person is profoundly affected. Even here, Bavinck is consistent that human nature retained its substance or essence after the fall, what it lost was its moral qualities that once naturally belonged to it; see Mattson, Restored, 162, 155; Cf. RD, 2:553-54. 
But the role of grace is to restore the forma, or in Bavinck's term to "reformed" the creation that was once "deformed". ${ }^{31}$

On employing the distinction of "form" and "essence", Bavinck is much more consistent than Kuyper, for he did not go that far to say that the form of the world would be destroyed. Those verses that seemingly imply the destruction of the present world-such as 2 Pet. 3:10 which is cited by Kuyper-are not talking about the total destruction of the present world, but its purification. As he wrote:

In the same way, the New Testament proclaims that heaven and earth will pass away (Matt. 5:18; 24:35; 2 Pet. 3:10; 1 John 2:17; Rev. 21:1), that they will perish and wear out like clothing (Heb. 1:11), dissolve (2 Pet. 3:10), be burned with fire (3:10), and be changed (Heb. 1:12). But none of these expressions implies a destruction of substance. Peter, for example, expressly teaches that the old earth, which originated as a result of the separation of waters, was deluged with water and so perished (2 Pet. 3:6), and that the present world would also perish, not-thanks to the divine promise-by water but by fire. The world was not totally destroyed in the flood, and so we must no more think of a destruction of substance with fire than we would do with water: fire burns, cleanses, purifies but does not destroy. ${ }^{32}$

God does not intend to destroy this world with his fire; instead, he intends to purify it from sin. That is why it is not a revolution, for revolution destroys the good with the bad, but reformation in the sense that only sin alone is destroyed. In Bartholomew's words: "sin can be eradicated without de- stroying the good creation, and grace can restore the creation without creating anew." 33

Bavinck also makes his case from 1 John $2: 17$, in which he argues that the statement "the world and its desire are passing away" is not implying the destruction of the world's substance but how the present world in its "sin-damaged form" will vanish. Furthermore, he also argues from 1 Corinthians $7: 31$, wherein Paul states that "the present form ( ò $\sigma \chi \tilde{\eta} \mu \alpha$, tò schema ) of this world is passing away" (ESV). In that way, Bavinck is more consistent in arguing that the renewal or restoration that is taught by the Scripture is not "a second" nor "brand-new creation," but "a re-creation of the existing world." 34 Thus, despite the shared theological position of re-creation among the two, Bavinck is much more consistent than Kuyper.

So we might want to adjust Bartholomew's critic a little bit because it is not Kuyper's distinction of form and essence, which is "unhelpful" since Bavinck could make such a distinction in a "helpful" way. However, the problem is in his elaboration on how the form of this present world will be going through God's restoration work. Besides, Neo-Calvinistic theology of re-creation has an optimistic view of this present world's future despite the grim reality of sin. Moreover, God would not fail to carry on his restorative work, for it is his glory that is at stake.

It is crucial to note that there is also a notion of the discontinuity between creation and new creation in Neo-Calvinism. The term "restoration" itself should not be understood as leading the creation backward to Adam's time; instead, it should refer to the restoration of all things to God's original plan for

\footnotetext{
${ }^{33}$ Bartholomew, Contours of the Kuyperian Tradition, 49.

${ }^{34} R D, 4: 717$.
} 
the creation since eternity. ${ }^{35}$ For Bavinck, "the state of glory" is not a "mere restoration" of nature, but "a re-formation" by Christ's power that brings "all potency into actuality" and thus, "presents the entire creation before the face of God, brilliant in unfading splendor and blossoming in a springtime of eternal youth." ${ }^{36}$ In Bartholomew's terms, that is not a "repristination," for it is not moving from "garden to garden" but from "garden to city." That is God's original plan for his creation. ${ }^{37}$ Bavinck vividly depicted the future city:

All that is true, honorable, just, pure, pleasing, and commendable in the whole of creation, in heaven and on earth, is gathered up in the future city of Godrenewed, re-created, boosted to its highest glory. The substance [of the city of God] is present in this creation. Just as the caterpillar becomes a butterfly, as carbon is converted into diamond, as the grain of wheat upon dying in the ground produces other grains of wheat, as all of nature revives in the spring and dresses up in celebrative clothing, as the believing community is formed out of Adam's fallen race, as the resurrection body is raised from the body that is dead and buried in the earth, so too, by the recreating power of Christ, the new heaven and the new earth will one day emerge from the fire-purged elements of this world, radiant in enduring glory and forever set free from the "bondage to decay." 38

In that vivid picture of the future city of God, Bavinck could maintain the balance between continuity and discontinuity of the old creation and the new. It is a restoration

\footnotetext{
${ }^{35}$ Conradie, "Revisiting Kuyper's Notion of Common Grace," 100.

${ }^{36} R D, 4: 720$.

${ }^{37}$ Bartholomew, Contours of the Kuyperian Tradition, 49.

${ }^{38} R D, 4: 720$.
}

in the sense that it springs out of the "elements" of the old creation. On the other hand, it will be a total renewal into an unimaginable glory that the creation had never achieved before. In that case, it is right to infer that the conviction "grace restores nature" means "grace perfects nature."

It is not only nature that will be transformed in such a glorious way but also "the blessed" or the people of God. Bavinck wrote:

The blessed will therefore not only be free from sin but also from all the consequences of sin, from ignorance and error (John 6:45), from death (Luke 20:36; 1 Cor. 15:26; Rev. 2:11; 20:6, 14), from poverty and disease, from pain and fear, hunger and thirst, cold and heat (Matt. 5:4; Luke 6:21; Rev. 7:16-17; 21:4), and from all weakness, dishonor, and corruption (1 Cor. 15:42; etc.). Still the spiritual blessings are the more important and innumerably abundant: holiness (Rev. 3:45; 7:14; 19:8; 21:27); salvation (Rom. 13:11; 1 Thess. 5:9; Heb. 1:14; 5:9); glory (Luke 24:26; Rom. 2:10; 8:18, 21); adoption (Rom. 8:23); eternal life (Matt. 19:16-17, 29; etc.); the vision of, and conformity to, God and Christ (Matt. 5:18; John 17:24; Rom. 8:29; 1 Cor. 13:12; 2 Cor. 3:18; Phil. 3:21; 1 John 3:2; Rev. 22:4); and fellowship with, and the service and praise of, God and Christ (John 17:24; 2 Cor. 5:8; Phil. 1:23; Rev. $4: 10 ; 5: 9-13 ; 7: 10,15-17 ; 21: 3 ; 22: 3$; etc.). ${ }^{39}$

That is indeed a beautiful description of how our future blessedness as God's people would be. It is rich, deep, and wide, and since God is the One who promises the future to us, we would not doubt that it will come to pass. However, up to this point, it has to be admitted that Neo-Calvinism is not

\footnotetext{
${ }^{39}$ Ibid., 720-21.
} 
unique to other theological traditions. Almost every Christian tradition believes that we would be free from sin and its consequences in heaven or the new creation. Nevertheless, what is unique from NeoCalvinism and its relevance for the meantime is the emphasis that God would carry on his promise of transforming all creation without first destroying it.

\section{TRINITARIAN THEOLOGY OF RE-CREATION}

Kuyper and Bavinck are consistently trinitarian when discussing re-creation. Bavinck affirms that it is the grace of the Trinity that would restore everything in nature that is affected by sin: "The love of the Father, the grace of the Son, and the communion of the Holy Spirit extend even as far as sin has corrupted." ${ }^{40}$ In another place, he explicitly uses the terms "creation" and "new creation": "God produces both creation and new creation by his Word and Spirit. By his speech, he calls all things into being out of nothing (Gen. 1; Ps. 33:6; John 1:3; Heb. 1:3; 11:3)." ${ }^{41}$ Even though the unity of the Trinity is maintained when discussing creation and re-creation, it is important to note that each person's distinctive role is not being diminished in Bavinck's theology. In his concise yet integral formulation, he wrote, "The essence of the Christian religion consists in the reality that the creation of the Father, ruined by $\sin$, is restored in the death of the Son of God and re-created by the grace of the Holy Spirit into a kingdom of God." 42 Here we can see that in Bavinck's theology-even though both creation and new creation is the work of the Trinity-re-creation is understood as the distinctive work of the Spirit. That is also Kuyper's position, as elaborated below.

\footnotetext{
${ }^{40}$ Bavinck, "Common Grace," 61.

${ }^{41} R D, 4: 33$.

${ }^{42} R D, 1: 112$.
}

Kuyper expounded how grace restores nature in a trinitarian motive without diminishing the distinctive role of each person of the Trinity. He wrote: "That in every work effected by Father, Son, and Holy Ghost in common, the power to bring forth proceeds from the Father; the power to arrange from the Son; the power to perfect from the Holy Spirit."43 Expressed differently, Kuyper was saying that all things are "originated" from the Father, "received consistency" from the Son, and "were led to their destiny" from the Holy Spirit. ${ }^{44}$ Kuyper was against the fixed restriction that God the Father is for our creation, the Son for our redemption, and the Holy Spirit for our sanctification. ${ }^{45}$ Instead, he argues that the Spirit's role is extending to all creation as also of the Father and the Son, but the Holy Spirit's distinct role over creation is "to perfect" or to lead all things (creation) to their destiny.

According to Kuyper, two "operations" appear during the creation: "first, the causative, which produces the materials, forces, and plans; second, the constructive, which with these forces forms and orders the materials according to the plan." The first is from the Father, and the second is from the Son. However, according to Kuyper, this "does not complete the work of creation." Because the creation has "purpose" and "destiny," and it will only be complete when it has totally become God's original design. To bring the creation into completion is the distinct work of the Holy Spirit, as Kuyper wrote: "Thus to lead the creature to its destiny; to cause it to develop according to its nature, to make it perfect, is the proper work of the Holy Spirit." ${ }^{\prime 6}$ Here we could see that both

${ }^{43}$ Abraham Kuyper, The Work of The Holy Spirit, trans. Hendri de Vries (New York: Funk \& Wagnalls, 1900), 19; emphases original.

${ }^{44}$ Ibid., 20.

${ }^{45}$ Ibid., 44.

${ }^{46}$ Ibid., 21; emphases original. 
Bavinck's and Kuyper's theology of recreation is trinitarian, yet with a powerful pneumatological emphasis.

There is also a christological emphasis in Kuyper's and Bavinck's theology of recreation. In Kuyper's theology, the christological emphasis could be seen through how he uses the notion of Christ's "perfect redemption." Whereas in Bavinck's, it could be seen through the notion of Christ as a "complete Savior." According to Kuyper, Christ is not only given to us for our justification and sanctification but, according to 1 Corinthians 1:30, also for our "wisdom" and "perfect redemption." In Christ, we have not only the atonement for our sin but also the promise of a transformation of our "lowly bodies" into the like of "his glorified body." And Kuyper does not consider the work of Christ at Golgotha as the end. Instead, it will culminate in leading the whole creation into "a new heaven and a new earth." Christ is the Savior of both the soul and the body, and he is the re-Creator, "not only of the things that are invisible but also of the things that are visible." And thus both the souls of the elects and the whole world will be his prize, "the trophy of his glory." ${ }^{47}$ Christ will not be Lord over the bodiless elects, but he will be Lord over the resurrected people of God living in the new heaven and the new earth at the end of time.

Christ's position as the "re-Creator" should not be confused with the Holy Spirit's distinct role that restores all things. In the salvific work of Christ, "the elect are brought to salvation through the work of the Holy Spirit with Christ as the mediator of salvation." In the restoration of all creation, "the world at large is restored by the Holy Spirit on the basis of Christ as mediator of creation." 48 In short, "this restoration is effected

\footnotetext{
${ }^{47} C G$ 1:267-68; quoted in Bartholomew, Contours of the Kuyperian Tradition, 38.

${ }^{48}$ Jeremy George Augustus Ive, "A Critically Comparative Kuyperian Analysis and a Trinitarian,
}

specifically by the Holy Spirit, but under the kingship of the Son." 49

For Bavinck, the relationship between Christ and re-creation could be found in the notion of Christ as a complete Savior. As he wrote, "The rebirth by water ad Spirit finds its completion in the rebirth of all things (Matt. 19:28). Spiritual redemption from sin is only fully completed in bodily redemption at the end of time. Christ is a complete Savior."50 The incarnation is rooted in the Trinity. It is also presupposed and prepared in the creation. Especially, the creation of humanity in the image of God, "is a supposition and preparation for the incarnation of God." Creation and redemption should not be seen separately, for in his act of creation, "God already had the Christ in mind." Bavinck explains further: "The world was so created that when it fell, it could again be restored; humanity was organized under a single head in such a way that, sinning, it could again be gathered together under another head. Adam was so appointed as head that Christ could immediately take his place; and the covenant of works was so set up that, broken, it could be restored in the covenant of grace." ${ }^{51}$ Therefore the view that says incarnation would take place even without sin coming into the world is wrong, for it is created in anticipation of its restoration. ${ }^{52}$ It does not mean that Christ's incarnation is grounded in sin and thus can be regarded as an accidental and arbitrary human action. Bavinck argues using Augustine's standpoint, which is followed by Reformed theology that, "there is but one plan and decree of God; with a view to the counsel of God, there is no room for any reality other than

\footnotetext{
'Perichoretic' Reconstruction of the Reformational Philosophies of Dirk H.Th. Vollenhoven and Herman Dooyeweerd" (Ph.D dissertation, King's College, London, 2012), 38.

${ }^{49}$ Ibid., 34.

${ }^{50} R D, 4: 694$.

${ }^{51} R D, 3: 277-78$.

${ }^{52}$ Ibid., 278.
} 
the existing one." Even though sin came into the creation through "the will of the creature," it was included in God's eternal counsel, and it was neither contingent nor unforeseen to him. ${ }^{53}$

Nothing surprises God, not sin nor its devastating effects. The creator God is the Redeemer of his creation. Through Christ, the "complete Savior," God first redeems his people, but then all of his created cosmos. This position allows believers to proclaim that the message of salvation is not salvation from the earth but the salvation of the whole earth.

\section{CONCLUSION}

First, despite the horrible effects of sin upon the whole world, God's plan is never to destroy it but to restore it. Evil is powerful, yet God's grace is even more. Furthermore, the extent of that grace is not just to the salvation of the elect, but all creation. God's redemptive work is working now on restoring all creation towards a new heaven and a new earth. Reflecting upon the new creation should not make Christians hate this present world, for grace is not alien to nature nor antithetical to it; instead, it restores nature. This very creation that we live now will be transformed as perfect as God's original plan for his creation.

Second, this present world (creation) is far from perfection, should encourage Christians to hope for the perfect new creation in the future. Even though the continuity between creation and the new creation is real, the difference is even more. Believers and all creation will be transformed into an unimaginable reality. Sin will be no more, and God's glory will be manifested fully as never before. Christians should long for that perfect and glorious reality, yet they should do so without fear. God's transforming work does

\footnotetext{
${ }^{53}$ Ibid., 279.
}

not include the destruction of this present world but total restoration.

Third, Christians are called to be God's agents of transformation. Those who are in Christ and indwelled by the Holy Spirit are the new creation (2 Cor. 5:17). The rebirth of all things begins with the rebirth of those who believe in Christ. Amid the pandemic, Christians should realize that God's restoration begins with them and now is progressing towards its fullness, which is the rebirth of all things. Even though God's work is not limited to the church, God has always been using his church as the transformation agent in this world. In society, Christians are called to actively attempt societal transformation, such as caring for those who are sick or in need, comfort those who lost their loved ones due to Covid-19, and any other ways that may help the society where they live. Moreover, within the church context, Christians are called not just to think about how to conduct worship services amid the pandemic but also the best way to proclaim to the world that God's salvation is given for those who believe in Christ and for the restoration of the whole creation.

\section{REFERENCES}

Bartholomew, Craig G. Contours of the Kuyperian Tradition: A Systematic Introduction. Downers Grove: InterVarsity, 2017.

Bavinck, Herman. Reformed Dogmatics, 4 Vols. Edited by John Bolt, translated by John Vriend. Grand Rapids: Baker Academic, 2003-2008.

—. "Common Grace." Translated by Raymond C. Van Leeuwen. Calvin Theological Journal 24, no. 1 (April 1989): 35-65.

Bolt, John. A Free Church, a Holy Nation: Abraham Kuyper's American Public Theology. Grand Rapids: Eerdmans, 2001.

Conradie, Ernest M. "Revisiting Kuyper's Notion of Common Grace." In Creation 
and Salvation: Dialogue on Abraham Kuyper's Legacy for Contemporary Ecotheology, edited by Ernst M. Conradie, 95-136. Leiden: Brill, 2011.

Dwiraharjo, Susanto. "Konstruksi Teologis Gereja Digital: Sebuah Refleksi Biblis Ibadah Online di Masa Pandemi Covid19." Epigraphe: Jurnal Teologi dan Pelayanan Kristiani 4, no. 1 (2020): 1-17. https://doi.org/10.33991/epigraphe.v4i1. 145.

Eglinton, James. "Bavinck's Organic Motif: Questions Seeking Answers." Calvin Theological Journal 45, no.1 (2010): 5171.

Gordon, Bruce. John Calvin's Institutes of the Christian Religion: A Biography. New Jersey: Princeton University Press, 2016.

Henderson, Roger. "Kuyper's Inch." Pro Rege 36, no. 3 (2008): 12-14. https://digital collections.dordt.edu/pro_rege/vol36/ iss $3 / 2$.

Ive, Jeremy George Augustus. "A Critically Comparative Kuyperian Analysis and a Trinitarian, 'Perichoretic' Reconstruction of the Reformational Philosophies of Dirk H.Th. Vollenhoven and Herman Dooyeweerd." Ph.D dissertation, King's College, London, 2012.

Klapwijk, Jacob. "Abraham Kuyper on Science, Theology and University." Philosophia Reformata 78, no. 1 (2013): 18-46. https://doi.org/10.1163/2211611790000537.

Kuyper, Abraham. A Centennial Reader. Edited by James D. Bratt. Grand Rapids: Eerdmans, 1998.

- Common Grace: God's Gifts for a Fallen World. Vol. 1. Edited by M. van der Maas, translated by Nelson D. Kloosterman. Bellingham: Lexham Press, 2015.

- Lectures on Calvinism. 1931. Reprint, Grand Rapids: Eerdmans, 2000.

- The Revelation of St. John. Translated by John H. de Vries. Grand Rapids: Eerdmans, 1963.
The Work of The Holy Spirit. Translated by Hendri de Vries. New York: Funk \& Wagnalls, 1900.

Lukuhay, Alexander Stevanus. "Analisis Teologis Mengenai Beribadah di Rumah di Tengah Pandemi Covid-19 di Indonesia." Visio Dei: Jurnal Teologi Kristen 2, no.1 (2020): 43-61. https://doi.org/10. 35909/visiodei.v2i1.87.

Mattson, Brian G. Restored to Our Destiny: Eschatology \& the Image of God in Herman Bavinck's Reformed Dogmatics. Leiden: Brill, 2012.

Ortlund, Dane C. "'Created Over a Second Time' or 'Grace Restoring Nature'? Edwards and Bavinck on the Heart of Christian Salvation." The Bavinck Review 3 (2012): 9-29. https://bavinckinsti tute.org/wp-content/uploads/2012/06/ TBR3a-Ortlund1.pdf.

Van der Kooi, Kees. "Gratia non tollit naturam, sed perficit" in Creation and Salvation: Dialogue on Abraham Kuyper's Legacy for Contemporary Ecotheology. Edited by Ernst M. Conradie, 213-222. Leiden: Brill, 2011.

Widjaja, Fransiskus Irwan, Candra Gunawan Marisi, T. Mangiring Tua Togatorop, and Handreas Hartono, "Menstimulasi Praktik Gereja Rumah di tengah Pandemi Covid-19." Kurios: Jurnal Teologi dan Pendidikan Agama Kristen 6, no. 1 (2020): 127-139. https://doi.org/10.30995/ kur.v6i1.166.

Wolters, Albert. "Dutch Neo-Calvinism: Worldview, Philosophy and Rationality" in Rationality in the Calvinian Tradition. Edited by H. Hart, J. van der Hoeven, and Nicholas Wolterstorff, 113-131. Eugene: Wipf and Stock, 2011.

- "The Nature of Fundamentalism." Pro Rege 15, no. 1 (1986): 2-9. https:// digitalcollections.dordt.edu/pro_rege/ vol15/iss1/2.

Wolterstorff, Nicholas. Until Justice and Peace Embrace: The Kuyper Lectures for 1981. Grand Rapids: Eerdmans, 1983. 